Article

\title{
Flotation Behavior of Diatomite and Albite Using Dodecylamine as a Collector
}

\author{
Ying Gao ${ }^{1,2}$, Yuexin Han ${ }^{2, *}$ and Wenbo $\mathrm{Li}^{2}$ \\ 1 College of Chemistry, Chemical Engineering and Environmental Engineering, Liaoning Shihua University, \\ Fushun 113001, Liaoning, China; yychengbao_1983@126.com \\ 2 School of Resources and Civil Engineering, Northeastern University, Shenyang 110819, Liaoning, China; \\ liwenbo32@163.com \\ * Correspondence: hanyuexin@mail.neu.edu.cn; Tel.: +86-024-83680602
}

Received: 11 July 2018; Accepted: 23 August 2018; Published: 27 August 2018

check for updates

\begin{abstract}
The flotation behaviors of diatomite and albite using dodecylamine (DDA) as a collector were investigated and compared. The pure mineral flotation results indicate that the flotability difference between albite and diatomite is above $87 \%$ at pH 5.5 to 10.5 . The recovery of albite improves with increasing DDA dosage at $\mathrm{pH} 5.5$ to 10.5. In the same $\mathrm{pH}$ range, diatomite has weaker flotability than albite, particularly in alkaline $\mathrm{pH}$ pulp. Zeta potential measurements indicate that diatomite has a higher negative surface charge than albite at pH 7 to 12, DDA interacts strongly with albite and weakly with diatomite. Thus, DDA preferentially absorbs on albite surface rather than diatomite under alkaline conditions. Fourier transform infrared spectra (FTIR) indicate that the amount of DDA adsorbed to albite is greater than that adsorbed to diatomite, under the same conditions. The adsorption of DDA on the surface of diatomite is investigated by using atomic force microscopy (AFM) for the first time. The adsorption of the collector DDA on the surface of albite per unit area is greater than that on diatomite. This accounts for the lower recovery of diatomite than that of albite.
\end{abstract}

Keywords: diatomite; albite; flotation; DDA collector

\section{Introduction}

Diatomite is a sedimentary rock primarily composed of the skeletons of microscopic single-celled aquatic plants called diatoms. Diatomite has a chemical formula of $\mathrm{SiO}_{2} \cdot \mathrm{nH}_{2} \mathrm{O}$ (i.e., amorphous silica) $[1,2]$. The genesis of diatomite provides it with useful characteristics such as high porosity, large pore volume, high adsorption capacity, and low weight [3]. These characteristics make it useful in filtration materials, catalyst carriers, insulation materials, functional fillers, and cement mixtures [4-6]. Local resources and economic development differ between countries, so their consumption and application of diatomite also differ. However, the diatomite is now widely applied as a carrier, adsorbent, and filter aid with high added value.

China ranks second in the world in diatomite reserves with nearly 2 billion tons of total reserves [7]. However, most of these reserves are low-grade [8]. Compared with high-grade diatomite, low-grade diatomite must first be purified through physical or chemical methods. The diatom content can be increased by removing gangue minerals (i.e., albite, quartz, clay, etc.) [9]. Current purification methods [10-18] include scrubbing, roasting, acid leaching, gravity dressing, classification, ultrasonic treatment, classification and various combined processes [19-21]. These methods are limited by their high water and acid consumption, long production cycles, and environmental pollution. Flotation is an effective method for fine mineral separation, but limited information is available about diatomite purification by flotation. Shi et al. [22] demonstrated the feasibility of using scrubbing-flotation to 
purify diatomite. However, the effects of the reagents and conditions on the purification of diatomite have not been reported in detail, and the flotation mechanism of diatomite remains unknown.

The current study investigates the flotation [23,24] behavior of pure diatomite and albite that are often present in low-grade diatomite. The differences in flotability between diatomite and albite are analyzed. The mechanisms of the interactions of these mineral surfaces with dodecylamine (DDA) are analyzed using FTIR, zeta potential measurements, and AFM. These findings lay a foundation for further studies of the flotation of low-grade diatomite.

\section{Materials and Methods}

\subsection{Samples and Reagents}

Diatomite used in this study was obtained from Linjiang, Jilin Province, China. Pure albite was obtained from Hengyang, Hunan Province, China. The chemical analyses of these two samples were as follows: diatomite: $97.01 \% \mathrm{SiO}_{2}, 0.05 \% \mathrm{Al}_{2} \mathrm{O}_{3}, 0.09 \% \mathrm{Fe}_{2} \mathrm{O}_{3}, 0.13 \% \mathrm{CaO}, 0.03 \% \mathrm{~K}_{2} \mathrm{O}, 0.06 \% \mathrm{MgO}$, 2.63\% L.O.I; albite: $69.28 \% \mathrm{SiO}_{2}, 19.46 \% \mathrm{Al}_{2} \mathrm{O}_{3}, 10.74 \% \mathrm{Na}_{2} \mathrm{O}, 0.23 \% \mathrm{Fe}_{2} \mathrm{O}_{3}, 0.21 \% \mathrm{~K}_{2} \mathrm{O}, 0.08 \% \mathrm{MgO}$. The minus $0.023 \mathrm{~mm}$ fractions of diatomite and albite were used for flotation tests. DDA was used as the collector. $\mathrm{NaOH}$ and $\mathrm{H}_{2} \mathrm{SO}_{4}$ were used as $\mathrm{pH}$ regulators. All reagents used were of analytical grade. Distilled water was used in all experiments.

\subsection{Micro-Flotation Tests}

Single mineral flotation tests were conducted in a hitch groove flotation cell. A prepared $4 \mathrm{~g}$ pure mineral sample was transferred into a plastic cell, to which $30 \mathrm{~mL}$ of distilled water was added. The pulp was stirred (1000 r/min) for 3 min before adding $\mathrm{NaOH}$ or $\mathrm{H}_{2} \mathrm{SO}_{4}$ solution to adjust the $\mathrm{pH}$ to the desired value of $1.8,2.15,2.5,3.5,4,4.5,5.5,6.5,7.5,8.5,9.5,10.5$, or 11.5. The reagents were added to the pulp every $3 \mathrm{~min}$, in the order of DDA then frother $2^{\#}$ oil. The suspension was stirred for $3 \mathrm{~min}$ after adding the desired amounts of reagents, and flotation was then conducted for $3 \mathrm{~min}$. Finally, the froth products and tailings were each weighed after drying at $100{ }^{\circ} \mathrm{C}$ for $10 \mathrm{~h}$. The flotation recovery was calculated by:

$$
\text { Froth recovery }(\%)=\frac{\mathrm{A}(\mathrm{g})}{\mathrm{A}(\mathrm{g})+\mathrm{B}(\mathrm{g})}
$$

in which $\mathrm{A}$ is the weight of foam product, and B is the weight of the product in the flotation cell.

\subsection{Measurements}

Zeta potentials were measured using a Zeta potential analyzer (Malvern Zetasizer Nano ZS90, Partech, St Austell, UK). An agate mortar was used to grind ore samples to obtain 2- $\mu \mathrm{m}$ particle size fractions. $10 \mathrm{mg}$ of mineral sample was added to $100 \mathrm{~mL}$ of ultra-pure water, and the resulting slurry was stirred by a magnetic stirrer for $3 \mathrm{~min}$. The $\mathrm{pH}$ of the solution was automatically adjusted using $\mathrm{HCl}$ or $\mathrm{NaOH}$ in the $\mathrm{pH}$ range of 1.8-11.5. The collector, $2.38 \times 10^{-4} \mathrm{~mol} / \mathrm{L}$ DDA, was then added, and the pulp was stirred for a further $3 \mathrm{~min}$. The uncertainty in the zeta potential as obtained from a minimum of 3 measurements was $\pm 2 \mathrm{mV}$.

A Nicolet 380-FTIR spectrometer (Nicolet, Waltham, MA, USA) was used to record FTIR spectra of minerals before and after their surface interaction with DDA. Spectra were collected in the range from $400 \mathrm{~cm}^{-1}$ to $4000 \mathrm{~cm}^{-1}$. Mineral $(2 \mathrm{~g})$ was added to $15 \mathrm{~mL}$ of deionized water, and the resulting slurry was stirred for $3 \mathrm{~min}$. The $\mathrm{pH}$ was then adjusted to 5.5, and the collector, $2.38 \times 10^{-4} \mathrm{~mol} / \mathrm{L}$ DDA, was added to the slurry. Finally, the sample was vacuum filtered and dried at room temperature, before being subjected to FTIR characterization.

The morphologies of DDA adsorbed on the surfaces of diatomite and albite were scanned by AFM (Bruker Multimode 8, Bruck, Karlsruhe, Germany) [25,26]. The above-prepared samples used for FTIR characterization were fixed onto glass slides. AFM images were collected in ScanAsyst mode, using an Au reflex coated probe at a $1 \mathrm{~Hz}$ scan rate and 512 lines per sample. 


\subsection{Assay of Diatom Content}

The flotation concentrate of the artificially mixed ore was roasted for $30 \mathrm{~min}$ at $700{ }^{\circ} \mathrm{C}$. According to $\mathrm{SiO}_{2}+2 \mathrm{NaOH} \rightarrow \mathrm{Na}_{2} \mathrm{O} \cdot \mathrm{SiO}_{2}+\mathrm{H}_{2} \mathrm{O}$, a certain quantity of diatomite was placed in $\mathrm{NaOH}$ solution, and the mixture was stirred for $2 \mathrm{~h}$ at $98{ }^{\circ} \mathrm{C}$, and then allowed to cool to ambient temperature. The content of $\mathrm{SiO}_{2}$ in the slag was analyzed after drying at $100{ }^{\circ} \mathrm{C}$ for $30 \mathrm{~min}$. The percentage of diatomite was calculated according to:

$$
\text { Percentage of diatom }(\%)=\frac{\mathrm{m}_{1}(\mathrm{~g})-\mathrm{m}_{2}(\mathrm{~g})}{\mathrm{M}(\mathrm{g})}
$$

in which $m_{1}$ is the mass of $\mathrm{SiO}_{2}$ in the calcined diatomite without $\mathrm{NaOH}$ treatment, $\mathrm{m}_{2}$ is the mass of $\mathrm{SiO}_{2}$ in the filtrate residue that was dissolved in $\mathrm{NaOH}$, and $\mathrm{M}$ is the mass of the sample before alkali dissolution.

\section{Results and Discussion}

\subsection{Flotation}

The flotation results of diatomite and albite as a function of $\mathrm{pH}$ using DDA as a collector are shown in Figure 1. The flotation recovery of diatomite increases as the $\mathrm{pH}$ is increased from 1.8 to 4 , then decreases sharply as the $\mathrm{pH}$ is further increased from 4 to 5.5 , and then plateaus as the $\mathrm{pH}$ is further increased from 5.5 to 11.5 . The maximum recovery of diatomite is $42 \%$. The flotation recovery of albite at $\mathrm{pH} 1.8$ is low. After a pH regulator is added, the recovery of albite markedly increases as the $\mathrm{pH}$ is increased to 2.5. Minimal further increase in albite recovery occurs as the $\mathrm{pH}$ is increased from 3.5 to 10.5. The albite recovery decreases dramatically when the $\mathrm{pH}$ is increased above 10.5. Figure 1 shows that the most efficient separation of albite from diatomite is achieved in the $\mathrm{pH}$ range from 5.5 to 10.5 .

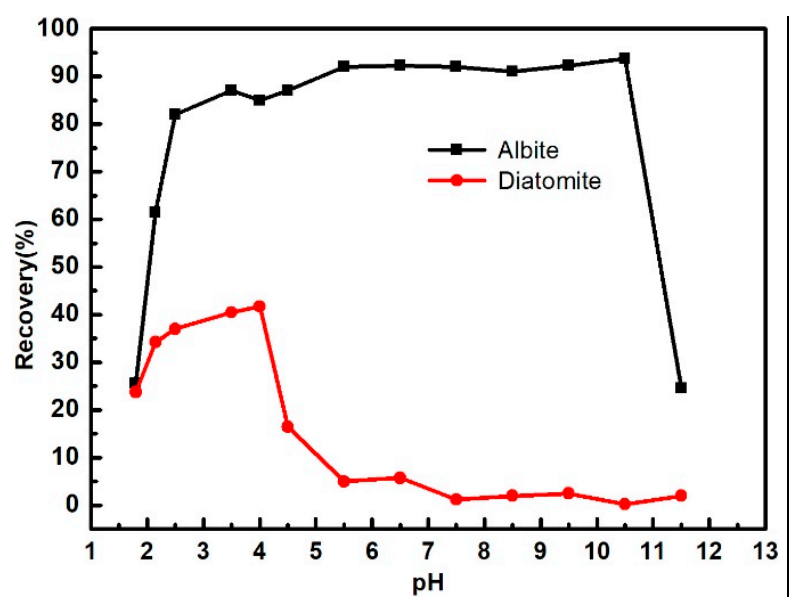

Figure 1. Recovery of diatomite and albite as a function of $\mathrm{pH}$ using $2.38 \times 10^{-4} \mathrm{~mol} / \mathrm{L}$ DDA.

The effect of DDA concentration on the flotability of diatomite and albite at pH 5.5, 7.5, and 10.5 is shown in Figure 2. The recovery of albite significantly increases after adding DDA. This recovery increase continues until the DDA concentration reaches $2.38 \times 10^{-4} \mathrm{~mol} / \mathrm{L}$, after which the recovery of albite changes little. When the DDA concentration is above $1.51 \times 10^{-4} \mathrm{~mol} / \mathrm{L}$, the recovery of diatomite slowly increases with increasing DDA concentration at $\mathrm{pH} 5.5$ and 7.5. The recovery of diatomite at $\mathrm{pH} 7.5$ is lower than that at $\mathrm{pH}$ 5.5. DDA addition has minimal influence on the diatomite flotation at $\mathrm{pH} 10.5$. At a DDA concentration of $2.38 \times 10^{-4} \mathrm{~mol} / \mathrm{L}$, the difference in recovery between diatomite and albite ranges from $87 \%$ to $94 \%$. 


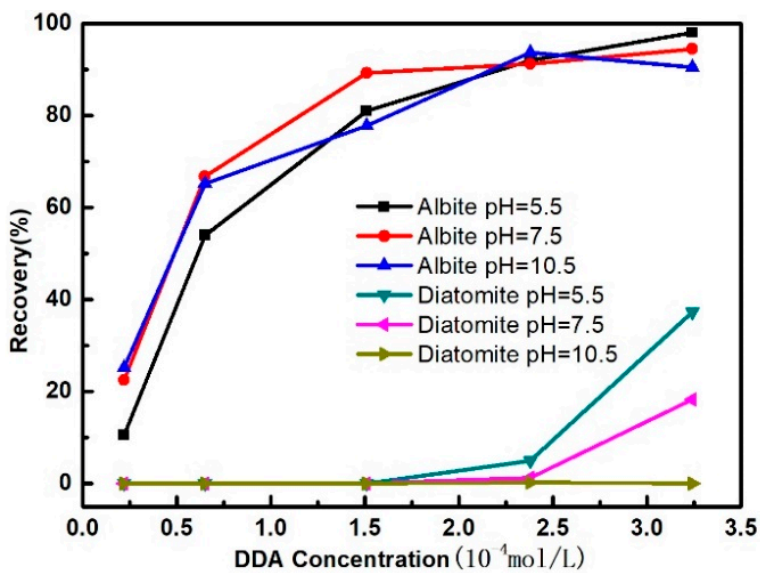

Figure 2. Flotation recovery as a function of DDA collector concentration at varying $\mathrm{pH}$.

The pure mineral flotation results indicate that DDA has strong collection properties towards albite and weak collection properties towards diatomite. To reduce the albite content in low-grade diatomite, reverse flotation separation experiments of artificially mixed ore (diatomite/albite $=4 / 1$ ) were conducted using $9.52 \times 10^{-4} \mathrm{~mol} / \mathrm{L} \mathrm{DDA}$ as a collector at $\mathrm{pH} 5.5$. The mixed ore, flotation concentrates, and tailings were characterized by XRD as shown in Figure 3.

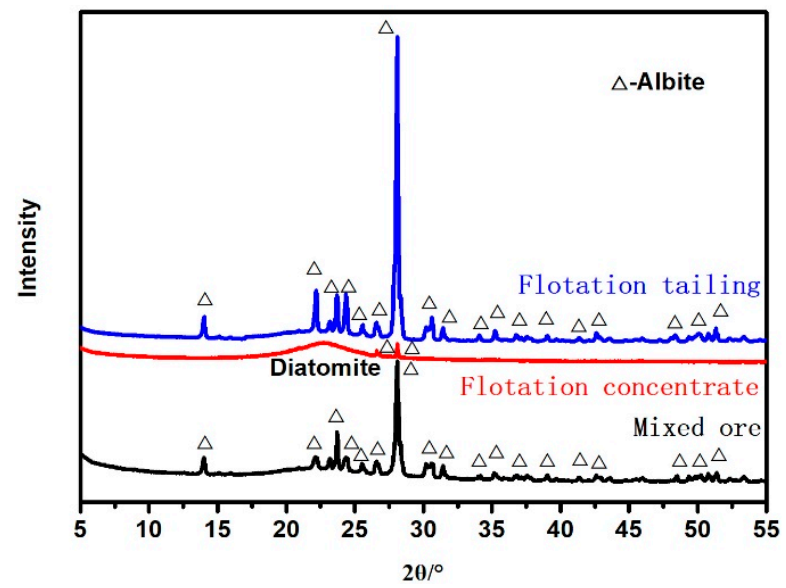

Figure 3. XRD patterns of the mixed ore, flotation concentrate, and tailings.

The XRD patterns of the artificially mixed minerals in Figure 3 show that the samples are composed of amorphous and crystalline materials. The amorphous material is diatom and the crystalline material is albite. There is a diffuse peak in the XRD pattern of the flotation concentrate, indicating that is mainly composed of amorphous material. The weaker XRD peak of albite indicates a small amount of albite in the flotation concentrate. The XRD pattern of the flotation tailings shows a strong characteristic peak of albite, indicating that it is the main component of the tailings. A broad peak at $2 \theta$ of $20-27^{\circ}$ indicates a small amount of diatomite in the tailings. The results of the flotation experiments of the artificially mixed samples show that DDA is an effective collector for separating albite from diatomite.

Diatom is amorphous so exhibits a broad diffuse XRD pattern. Thus, the content of diatom cannot be calculated directly by XRD. To quantify the diatom content, the high temperature alkali solution was used to analyze the concentrate. The content of diatom in the concentrate was about $93 \%$. This demonstrates that reverse flotation can be used to separate diatomite and albite with a DDA collector at pH 5.5. 


\subsection{Mechanism Analyses}

Zeta potential tests of diatomite and albite were measured at different $\mathrm{pH}$ values, as shown in Figure 4. The isoelectric point (IEP) of diatomite and albite occur at pH 2.0 and 1.8, respectively. The surface of diatomite and albite are negatively charged when the $\mathrm{pH}$ is above the IEP. At $\mathrm{pH}$ 4.5 to 10.5 , the zeta potential of diatomite becomes progressively more negative with increasing $\mathrm{pH}$, whereas minimal change occurs in the zeta potential of albite.

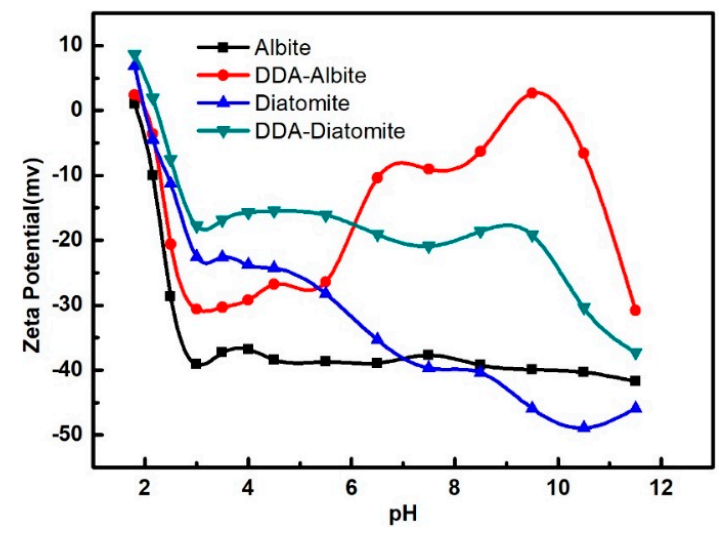

Figure 4. Zeta potentials of diatomite and albite.

When DDA is introduced into the pulp in the $\mathrm{pH}$ range of 1.8 to $10.5, \mathrm{RNH}_{3}{ }^{+}$of DDA may be electrostatically attracted to the diatomite and albite surfaces, thereby increasing the zeta potentials of diatomite and albite [27]. However, Figure 4 shows that the zeta potential of albite increases more than that of diatomite. At $\mathrm{pH}$ higher than 4.2, DDA molecules begin to form. Under these conditions, the dimer in solution has higher activity than the monomer. The dimer can readily adsorb to the surface of albite, so the Zeta potential increases significantly with increasing $\mathrm{pH}$ [28]. However, the adsorption of DDA on diatomite is relatively weak. It is speculated that the adsorption of DDA on the two minerals differs because of their different surface structures. DDA mainly exists in the form of a neutral molecule at $\mathrm{pH}$ higher than 10.5 (Figure 5). Thus, no electrostatic forces exist between DDA molecules and the diatomite or albite surfaces [29]. This results in the rapidly decreasing zeta potentials of DDA-diatomite and DDA-albite with increasing $\mathrm{pH}$ above 10.5. The zeta potentials show that the intensity of interaction between diatomite and DDA is lower than that between albite and DDA, which explains why the recovery of diatomite is lower than that of albite.

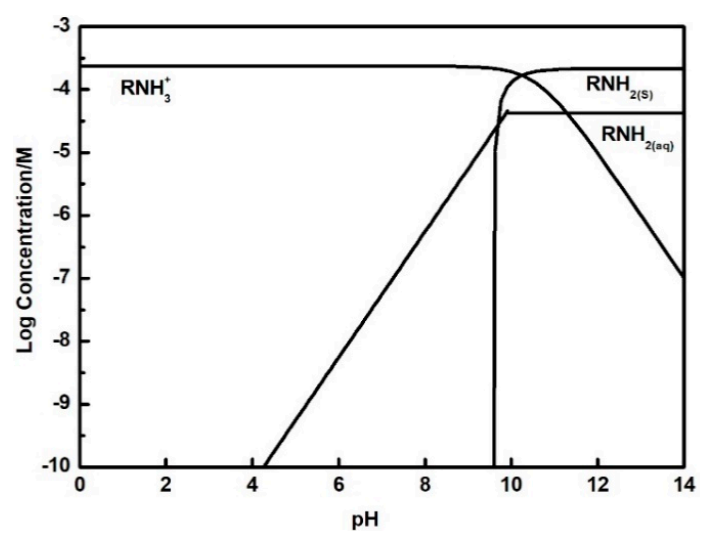

Figure 5. Logarithmic concentration diagram of DDA solution components.

FTIR spectra of diatomite and albite treated with $2.38 \times 10^{-4} \mathrm{~mol} / \mathrm{L}$ DDA at $\mathrm{pH} 5.5$ are shown in Figure 6. The bands at $2919 \mathrm{~cm}^{-1}$ and $2852 \mathrm{~cm}^{-1}$ are characteristic of the stretching vibrations of 
$-\mathrm{CH}_{2}$ - and $-\mathrm{CH}_{3}$ in diatomite, respectively. The corresponding bands in the albite spectrum occur at $2918 \mathrm{~cm}^{-1}$ and $2852 \mathrm{~cm}^{-1}$, respectively. The bands of the $-\mathrm{NH}_{2}$ flexural vibration are observed at $1628 \mathrm{~cm}^{-1}, 1518 \mathrm{~cm}^{-1}$ and $1471 \mathrm{~cm}^{-1}$ in the spectrum of diatomite. The corresponding bands in the spectrum of albite occur at $1599 \mathrm{~cm}^{-1}, 1520 \mathrm{~cm}^{-1}$ and $1506 \mathrm{~cm}^{-1}$, respectively. When DDA is adsorbed, the intensities of the $-\mathrm{CH}_{2}$ - and $-\mathrm{CH}_{3}$ stretching vibrations of albite increase more sharply than those of diatomite. The adsorption of DDA on the surface of diatomite is weaker than that on albite, because of the higher number of active sites on the albite surface. Thus, the FTIR bands of the $-\mathrm{CH}_{2}-$ and $-\mathrm{CH}_{3}$ stretching vibrations differ on the two mineral surfaces [30]. Figure 6 shows that the adsorption of DDA on albite and diatomite differ significantly at $\mathrm{pH} 5.5$.

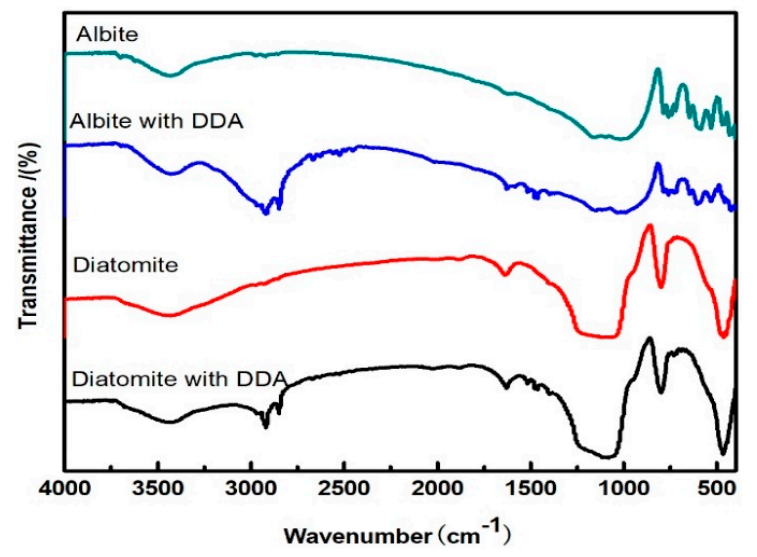

Figure 6. FTIR spectra of untreated diatomite and albite, and FTIR spectra of diatomite and albite treated with $2.38 \times 10^{-4} \mathrm{~mol} / \mathrm{L} \mathrm{DDA}$ at $\mathrm{pH} 5.5$.

The zeta potential and FTIR spectroscopy results indicate that the amount of DDA adsorbed on the surface of diatomite is less than that adsorbed on the surface of albite. The pore structure of diatomite is formed by defects, so abundant bonding sites exist on the edges of pores on the surface. It is speculated that DDA preferentially adsorbs at bonding sites on the edges of the pores, and that DDA does not readily adsorb on the diatomite surface at pore edges. In contrast, albite has more active sites that can adsorb a large amount of DDA, thus endowing it with good flotation behavior. AFM was used to characterize the adsorbed state of DDA on the surfaces of diatomite and albite.

Figure 7 shows 2D and 3D AFM images of the morphology of the fractured albite surface. The images show that the fracture surface of albite is relatively flat, and that no impurities or other reagents exist.

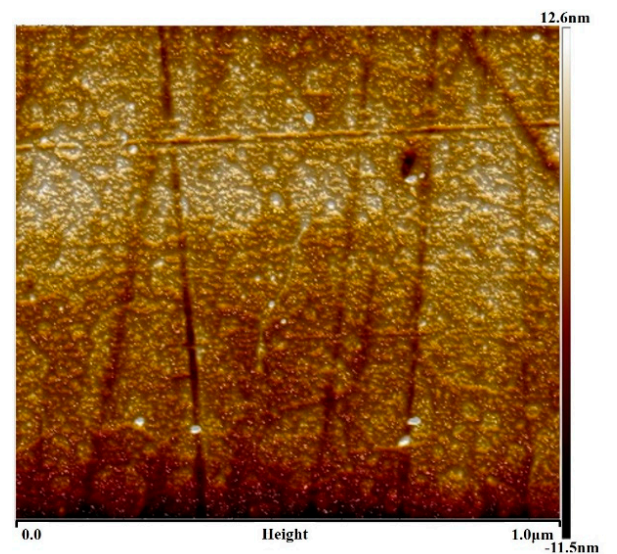

(a)

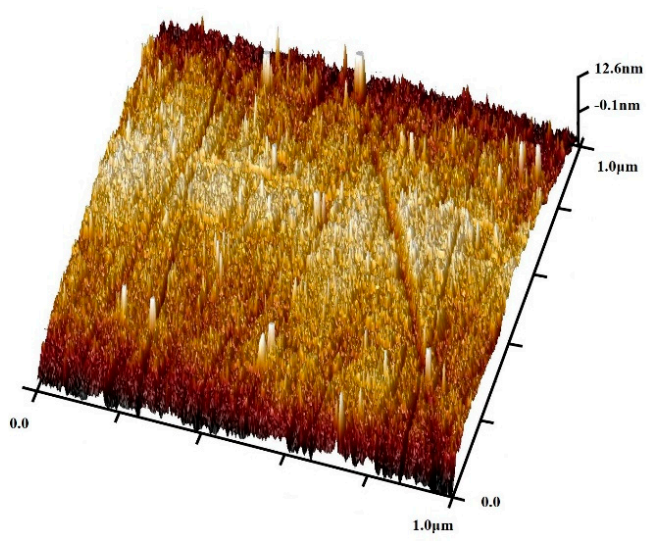

(b)

Figure 7. AFM (a) 2D and (b) 3D images of untreated albite. 
AFM images of albite treated with $2.38 \times 10^{-4} \mathrm{~mol} / \mathrm{L}$ DDA at $\mathrm{pH} 5.5$ are shown in Figure 8 . A large amount of DDA is adsorbed on the surface of albite, mostly by agglomeration. This is due to the dissolution of sodium ions from albite into solution, generating a large number of positive holes on the surface, to which DDA adsorbs well [31]. Figure 8c indicates that the thickness of the adsorbed DDA layer on the albite surface is $2-4 \mathrm{~nm}$. The length of the DDA molecule is about $1.78 \mathrm{~nm}$. It can thus be inferred that DDA exists as both a bilayer and monolayer on the albite surface.

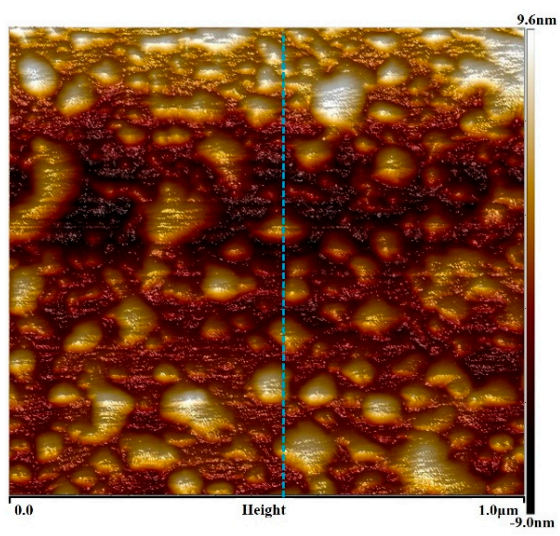

(a)

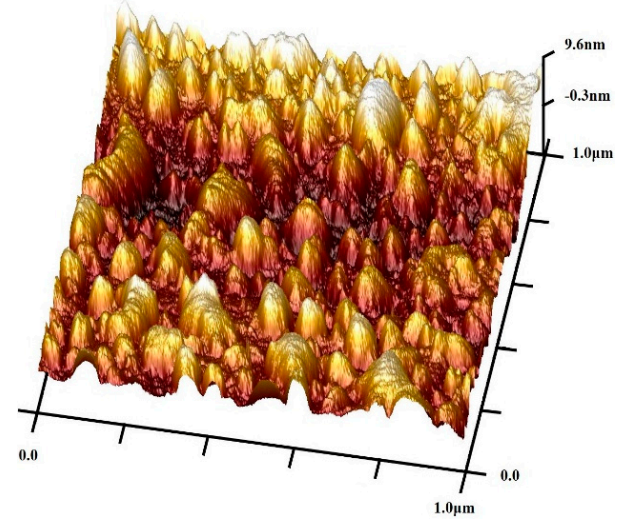

(b)

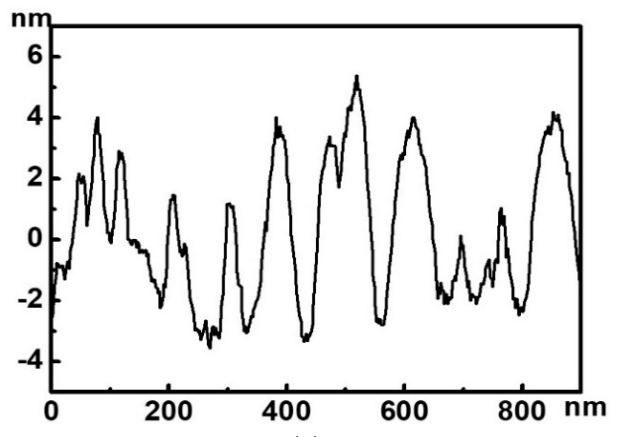

(c)

Figure 8. AFM (a) 2D and (b) 3D images of albite treated with $2.38 \times 10^{-4} \mathrm{~mol} / \mathrm{L} \mathrm{DDA}$ at pH 5.5, and (c) thickness of adsorbed DDA layer on the surface of albite.

2D and 3D AFM images of diatomite are shown in Figure 9a,b, respectively. There are many pores on the surface of diatom. The edges of the diatom pores are smooth, and no impurities are observed on the surface.

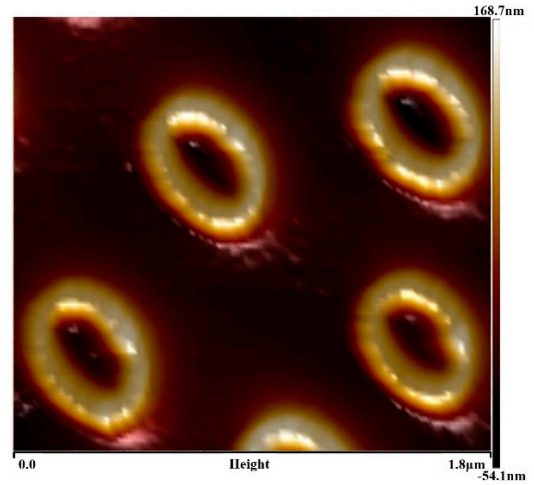

(a)

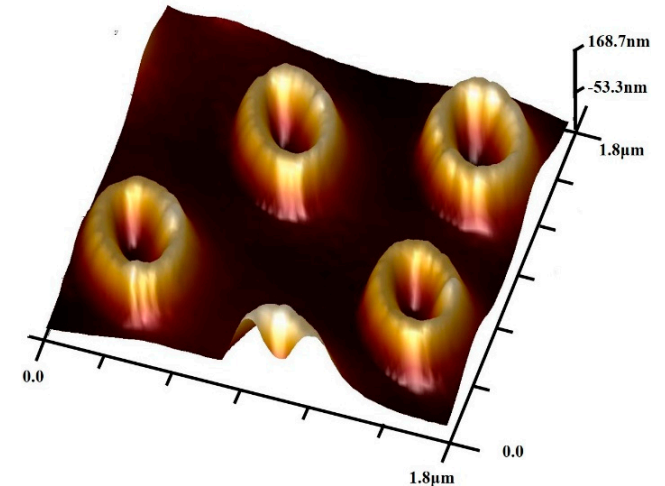

(b)

Figure 9. AFM (a) 2D and (b) 3D images of untreated diatomite. 
AFM was also used to characterize diatomite treated with $2.38 \times 10^{-4} \mathrm{~mol} / \mathrm{L}$ DDA at $\mathrm{pH}$ 5.5. Figure $10 \mathrm{a}, \mathrm{b}$ shows that DDA is adsorbed on the edges of diatomite pores, and is not observed on the other surfaces of diatomite. Diatomite is known to contain many hydroxyl groups on the edges of diatom pores, thus providing a large number of active sites [31]. DDA therefore adsorbs well to the pore edges. Figure 10c shows that the adsorbed DDA layer on the pore edges is non-uniform, and far thicker than the length of the DDA molecule. Therefore, the adsorption of DDA on the edges of the diatomite pores is considered to be multi-layer adsorption.

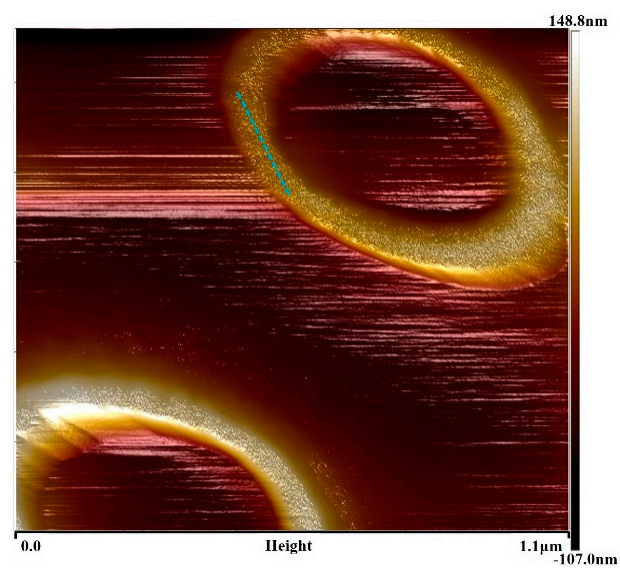

(a)

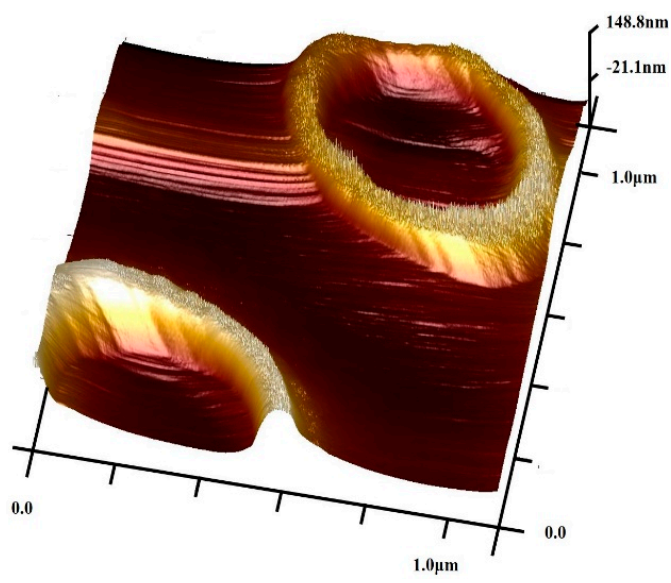

(b)

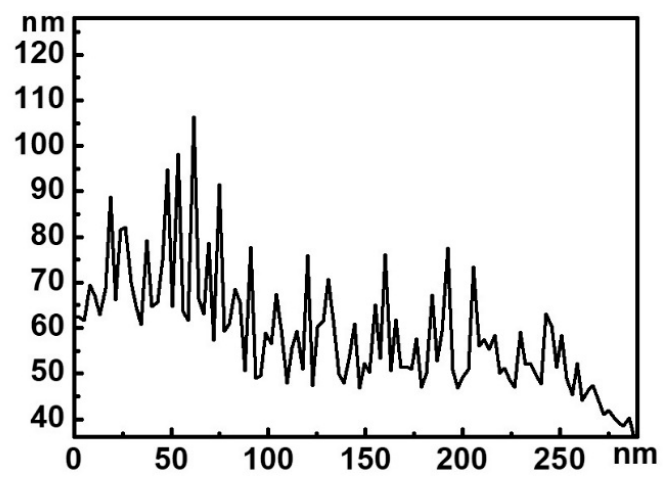

(c)

Figure 10. AFM (a) 2D and (b) 3D images of diatomite and albite treated with $2.38 \times 10^{-4} \mathrm{~mol} / \mathrm{L}$ DDA at $\mathrm{pH} 5.5$, and (c) thickness of adsorbed DDA layer on the surface of diatomite.

The AFM images of albite and diatomite indicate that DDA only adsorbs on the edges of pores on the diatomite surface, while the surface of albite adsorbs a large amount of DDA. This is consistent with predictions. The results show that the adsorption capacity of DDA on per unit area of diatomite is less than that on albite. This results in the flotability of diatomite being inferior to that of albite.

\section{Conclusions}

This study investigated the different flotation performances of albite and diatomite using DDA as a collector. The adsorption and morphology of DDA on the albite and diatomite surfaces were also investigated. The results show different flotation recoveries in the pulp at pH 5.5 to 10.5, and that the flotability difference between albite and diatomite is more than $87 \%$. The recovery of albite increases with increasing DDA dosage at $\mathrm{pH} 5.5$ to 10.5. In the same $\mathrm{pH}$ range, diatomite exhibits weaker flotability than albite, particularly in alkaline pulp. Zeta potential measurements and FTIR spectra indicate that the adsorption of DDA on diatomite is weaker than that on albite. AFM images show 
that DDA adsorbs on the whole surface of albite, but only of the edges of diatomite pores. This results in diatomite and albite exhibiting differing flotabilities.

Author Contributions: Conceptualization, Y.H.; Data curation, Y.G. and Y.H.; Investigation, Y.G.; Software, Y.G.; Writing-original draft, Y.G.; Writing-review \& editing, Y.G., Y.H. and W.L.

Funding: This creative research work was supported by the National Natural Science Foundation of China (Grant No. 51604064), the Fundamental Research Funds for the Central Universities (Grant No. 150103003) and the Doctoral Scientific Research Foundation of Liaoning Province (201601027), for which the authors express their appreciation.

Conflicts of Interest: The authors declare no conflict of interest.

\section{References}

1. AI, X.S.; He, M.Z.; Han, Y.X. Study on purifying Chifeng diatomite. Non-Ferrous Min. Metall. 2002, 18, $14-16,20$.

2. Yllmaz, B.; Ediz, N. The use of raw and calcined diatomite in cement production. Cem. Concr. Compos. 2008, 30, 202-211. [CrossRef]

3. Jiang, Y.Z.; Jia, S.Y. Exploitation application existing conditions and evolution of diatomite. Non-Ferrous Min. Metall. 2011, 27, 31-37.

4. De Namor, A.F.; El Gamouz, A.; Frangie, S.; Martinez, V.; Valiente, L.; Webb, O.A. Turning the volume down on heavy metalsusing tuned diatomite. A review of diatomite and modified diatomite for theextraction of heavy metals from water. J. Hazard. Mater. 2012, 241, 14-31. [CrossRef] [PubMed]

5. Dantas, T.N.D.; Neto, A.A.D.; Moura, M.C.P. Removal of chromium from aqueoussolutions by diatomite treated with microemulsion. Water Res. 2001, 3, 2219-2224. [CrossRef]

6. Petra, H.; Karl, E.R.; Kurt, C. Sorption of Nonpolar aromatic contain in ants by chlorosilane surface modified natural minerals. Environ. Sci. Technol. 2001, 35, 4260-4264.

7. Zhao, H.S.; He, W.; Luo, S.Q.; Jia, X.T.; Feng, Y.J.; Li, Z.M. Progress in studies and applications of diatomite. J. Shandong Inst. Light Ind. 2007, 21, 80-82.

8. Zhang, F.J. The Processing and Application of Diatomite; Chemical Industry Press: Beijing, China, 2006.

9. $\mathrm{Lu}, \mathrm{H}$. Diatomite resource and its situation of development and utilization. Geol. Zhejiang 2001, 17, 52-59.

10. Ediz, N.; Bentli, İ; Tatar, İ. Improvement in filtration characteristics of diatomite by calcinations. Int. J. Miner. Process. 2010, 94, 129-134. [CrossRef]

11. Şan, O.; Gören, R.; Özgür, C. Purification of diatomite powder by acid leaching for use in fabrication of porous ceramics. Int. J. Miner. Process. 2009, 93, 6-10. [CrossRef]

12. Şan, O.; İmaretli, A. Preparation and filtration testing of diatomite filtering layer by acid leaching. Ceram. Int. 2011, 37, 73-78. [CrossRef]

13. Goren, R.; Baykara, T.; Marsoglu, M. A study on the purification of diatomite in hydrochloric acid. Scand. J. Metall. 2002, 31, 115-119. [CrossRef]

14. Sun, Z.M.; Yang, X.P.; Zhang, G.X.; Zheng, S.; Frost, R.L. A novel method for purification of low grade diatomite powders in centrifugal fields. Int. J. Miner. Process. 2013, 125, 18-26. [CrossRef]

15. Zhang, G.; Cai, D.; Wang, M. Microstructural modification of diatomite by acid treatment, high-speed shear, and ultrasound. Microporous Mesoporous Mater. 2013, 165, 106-112. [CrossRef]

16. Goren, R.; Baykara, T.; Marsoglu, M. Effects of purification and heat treatment on pore structure and composition of diatomite. Br. Ceram. Trans. 2002, 101, 177-180. [CrossRef]

17. Sun, Z.M.; Bai, C.H.; Zheng, S.L.; Yang, X.; Frost, R.L. A comparative study of different porous amorphous silica minerals supported $\mathrm{TiO}_{2}$ catalysts. Appl. Catal. A Gen. 2013, 458, 103-110. [CrossRef]

18. Yuan, P.; Yang, D.; Lin, Z.Y.; He, H.; Wen, X.; Wang, L.; Deng, F. Influences of pretreatment on the surface silylation of diatomaceous amorphous silica with trimethylchlorosilane. J. Non-Cryst. Solids 2006, 352, 3762-3771. [CrossRef]

19. Ibrahim, S.S.; Selim, A.Q. Producing a micro-porous diatomite by a simple classification-calcination process. J. Ore Dress. 2010, 2, 25-33.

20. Ibrahim, S.S.; Selim, A.Q. Heat treatment of natural diatomite. Phys. Chem. Probl. Miner. Process. 2012, 48, $413-424$. 
21. Kunwadee, R.; Aphiruk, C. Thermal an acid treatment on natural raw diatomite influencing in synthesis of sodium zeolite. Porous Mater. 2007, 2, 98-106.

22. Shi, D.M.; Zhang, Z.H. Study on purification of diatomite in Yunnan Xundian. Non-Metall. Mines 1993, 1, 7-10, 63 .

23. Kou, J.; Tao, D.; Xu, G. Fatty acid collectors for phosphate flotation and their adsorption behavior using QCM-D. Int. J. Miner. Process. 2010, 95, 1-9. [CrossRef]

24. Zhang, W.C.; Honaker, R. Studies on carbon flotation from fly ash. Fuel Process. Technol. 2015, 139, $236-241$. [CrossRef]

25. Xing, Y.; Gui, X.; Pan, L.; Pinchasik, B.E.; Cao, Y.; Liu, J.; Kappl, M.; Butt, H.J. Recent experimental advances for understanding bubble-particle attachment in flotation. Adv. Colloid Interface Sci. 2017, 246, 105-132. [CrossRef] [PubMed]

26. Xing, Y.; Xu, M.; Gui, X.; Cao, Y.; Babel, B.; Rudolph, M.; Weber, S.; Kappl, M.; Butt, H.J. The application of atomic force microscopy in mineral flotation. Adv. Colloid Interface Sci. 2018, 256, 373-392. [CrossRef] [PubMed]

27. Vidyadhar, A.; Hanumantha Rao, K.; Forssberg, K.S. Adsorption of N-tallow 1,3-propanediamine-dioleate collector on albite and quartz minerals, and selective flotation of albite from greek stefania feldspar ore. J. Colloid Interface Sci. 2002, 248, 19-29. [CrossRef] [PubMed]

28. Liu, Y.C.; Gong, H.G. Adsorption mechanism of dodecyl amine-hydrochloride on feldspar and quartz and effect of pH. China Min. Mag. 1992, 2, 89-93.

29. Liu, C.M.; Hu, Y.H.; Feng, A.S.; Guo, Z.; Cao, X. The behavior of N, N-dipropyl dodecyl amine as a collector in the flotation of kaolinite and diaspora. Miner. Eng. 2011, 24, 737-740. [CrossRef]

30. Zhang, Z.; Feng, Q.M.; Wang, W.Q. Adsorption of Dodecyl Amine and Sodium Dodecyl Sulfonate on Feldspar and Quartz. Non-Metall. Mines 2012, 35, 8-15.

31. Zhang, W.C.; Honaker, R. Surface charge of rare earth phosphate (monazite) in aqueous solutions. Powder Technol. 2017, 318, 263-271. [CrossRef] 